\title{
HUBUNGAN PENGGUNAAN MEDIA ELEKTRONIK (GADGET) DENGAN PERKEMBANGAN SOSIAL ANAK USIA SEKOLAH
}

\author{
Aristina Halawa*, Maria Yustina Kristanti Ina Palan** \\ *Email : halawaaristina@yahoo.co.id
}

\begin{abstract}
ABSTRAK
Penggunaan media elektronik (gadget) pada anak usia sekolah dapat menjadi salah satu faktor yang mempengaruhi interaksi sosial dengan lingkungan sekitarnya sehingga anak menjadi individualisme. Tujuan penelitian ini adalah mengidentifikasi hubungan penggunaan gadget dengan perkembangan sosial anak usia sekolah. Penelitian ini menggunakan desain penelitian korelasional. Penelitian ini dilakukan di Madrasah Ibtidaiyah Darussalam Pagesangan Surabaya, dengan jumlah responden 73 siswa. Pengambilan sampel dilakukan dengan cara Stratified random sampling. Instrumen yang digunakan adalah kuesioner penggunaan gadget dan perkembangan sosial anak usia sekolah. Dari 73 responden didapatkan sebanyak 63 responden $(86,3 \%)$ menggunakan gadget pada tingkat sedang dan sebanyak 64 responden $(87,7 \%)$ memiliki perkembangan sosial yang baik. Hasil uji statistik dengan Spearman $=p: 0,000$ dengan nilai kemaknaan $\mathrm{p}<0,005$ yang yang berarti ada hubungan antara penggunaan media elektronik gadget dengan perkembangan sosial anak usia sekolah. Penggunaan gadget yang sesuai dan terkontrol oleh pihak sekolah dan orangtua dapat mempengaruhi perkembangan social anak menjadi baik. Untuk itu bagi orangtua diharapkan agar dapat meluangkan waktunya untuk mengontrol anak mereka saat menggunakan gadget dan bagi pihak sekolah diharapkan dapat memberikan stimulasi pada siswa dan siswi dalam bentuk kegiatan-kegiatan sosial di sekolah yang dapat mengembangkan sikap sosial anak.
\end{abstract}

Kata kunci: Penggunaan gadget, Perkembangan sosial anak usia sekolah.

\section{ABSTRACT}

The use of electronic media (gadgets) in school age children can be one of the factors that affect social interaction with the surrounding environment so that the child becomes individualism. The purpose of this study is to identify the relationship of use gadgets with social development of children of school age. This research uses a correlational study design. This research was conducted in Darussalam Islamic elementary schools In Pagesangan Surabaya, with the number of respondents are 73 students. Sampling was done by stratified random sampling. The instrument used was a questionnaire the use of gadgets and social development of children of school age. Of the 73 respondents found as many as 63 respondents (86.3\%) use the gadget at a moderate level, and as many as 64 respondents (87.7\%) had a good social development. Results of statistical test by Spearman $=p: 0.000$ with significance value of $p<0.005$ which means there is a relationship between the use of electronic media gadgets with social development of children of school age. The use of appropriate gadgets and controlled by the school and parents can affect the social development of children to be good. For that to parents are expected to devote his time to control their children while using the gadget and for the school is expected to provide stimulation to the male and female students in the form of social activities at school to develop a child's social attitudes.

Keywords: Use of gadgets, social development of school age children 


\section{Pendahuluan}

Pada zaman sekarang ini perkembangan teknologi dan informasi atau yang lebih dikenal dengan "Gadget" mengalami kemajuan yang sangat pesat baik di negara maju maupun di negara berkembang seperti Indonesia dan digunakan oleh seluruh lapisan masyarakat baik dewasa maupun anak-anak. "Gadget" merupakan alat canggih dengan berbagai aplikasi yang dapat menyajikan berbagai media berita, jejaring sosial, hobi, bahkan hiburan. Adanya aplikasinya yang selalu diperbaharui, gadget ini sering digunakan dikalangan usia dewasa untuk berkomunikasi dan urusan pekerjaan mereka seperti pekerjaan kantoran dan sebagainya. Akan tetapi pada faktanya gadget ini sering kita lihat juga digunakan oleh anak-anak khususnya anak usia sekolah yang seharusnya belum layak untuk menggunakannya, karena penggunaan gadget ini dapat membuat seorang anak menjadi individulisme dan apatis jika tidak terkontrol. Menurut Wong (2009) anak usia sekolah adalah anak pada usia 6-12 tahun, yang artinya sekolah menjadi tugas utama anak. Pada periode ini salah satu tugas perkembangan pada masa sekolah adalah belajar bergaul dengan teman-teman sebaya yakni belajar menyesuaikan diri dengan lingkungan sekitarnya seperti berinteraksi dan bersosialisasi dengan teman-teman sebayanya. Menurut Samsyu Yusuf (2014) perkembangan sosialnya merupakan pencapaian kematangan dalam hubungan sosial. Dapat juga diartikan sebagai proses belajar untuk menyesuaikan diri terhadap norma-norma kelompok, moral, dan tradisi; meleburkan diri menjadi satu kesatuan dan saling berkomunikasi dan bekerjasama. Perkembangan sosial pada anak-anak sekolah dasar ditandai dengan adanya perluasan hubungan, di samping dengan keluarga dia juga mulai membentuk ikatan baru dengan teman sebaya sehingga ruang gerak hubungan sosialnya bertambah luas. Kemampuan sosial anak ini dapat diperoleh dari berbagai kesempatan dan pengalaman bergaul dan bersinteraksi serta bersosialisasi dengan orang-orang di lingkungannya. Tetapi yang terjadi sekarang, kemampuan sosial anak terlebih anak usia sekolah semakin menurun dan ruang gerak sosialnya semakin sempit sebagai akibat dari penggunaan gadget di kalangan anak usia sekolah yang mempengaruhi interaksi sosial mereka dengan teman-teman sebaya yang ada di lingkungan sekitar. Mereka lebih suka menyendiri dan tidak peduli terhadap temanteman sebayanya dan lingkungan sekitarnya (Elizabeth, 2014). Hal ini juga ditemukan oleh penulis pada saat melakukan wawancara di Madrasah Ibtidaiyah Darusalam Pagesangan Surabaya ada siswa yang mengatakan bermain gadget tetapi bersama teman-temannya, dan ada juga yang mengatakan bermain gadget tetapi bersama teman-temannya, dan yang lainnya mengatakan tidak menggunakan gadget sama sekali. Padahal yang seharusnya diharapkan pada anak usia sekolah ini mampu belajar bergaul dan bersosialisasi dengan teman sebayanya dan lingkungan sekitarnya.

Berdasarkan penelitian Yulia Trinika, dkk (2014) di TK swasta Kristen Immanuel Pontianak tentang pengaruh penggunaan gadget terhadap perkembangan psikososial, menunjukan bahwa dari data-data yang terkumpul sebagian besar anak-anak usia sekolah menggunakan gadget dengan menghabiskan waktu yang cukup lama dan lebih suka menggunakan gadgetnya dibandingkan bermain dengan teman sebayanya, bahkan ada yang hanya berinteraksi dengan keluarga dan temanteman sebayanya jika membutukan sesuatu. Dan menurut penelitian yang sama oleh Nofri salman di SDN 006 Kanggini Bangkiang Kampar menemukan sebagian besar anakanak usia sekolah menggunakan gadget baik di sekolah maupun di rumah. Anak-anak sekolah yang menggunakan gadget tersebut mengalami kesenjangan dalam interaksi sosial dengan teman-teman sebayanya, lingkungan sekitarnya maupun orangtua dan hal ini berpengaruh pada prestasi belajar mereka di sekolah. Berdasarkan studi pendahuluan yang dilakukan penulis di Madrasah Ibtidaiyah Darusalam Pagesangan Surabaya yang dilakukan dengan cara wawancara pada 30 anak kelas IV dan V, penulis menemukan terdapat 25 anak menggunakan gadget dan 5 anak tidak menggunakan gadget. Dari 25 anak yang menggunakan gadget 20 anak mengatakan lebih suka menyendiri, malas bermain dan berkumpul bersama dengan teman-temannya. karena dia sudah terbiasa menyendiri dan lebih asyik bermain dengan gadgetnya. 
Sedangkan 5 anak yang lainnya mengatakan dia menggunakan gadget namun masih mau bermain dan berkumpul bersama temantemannya, bahkan anak tersebut memperbolehkan teman-temannya untuk bermain bersama dengan menggunakan gadget yang dimilikinya. 5 anak yang lainnya yang tidak menggunakan gadget mengatakan dia lebih suka bermain bersama temantemannya daripada asyik sendiri menggunakan gadget, selain itu mereka juga mengatakan dilarang oleh orang tuanya karena takut mengganggu pelajaran di sekolah.

Anak yang sudah terperangkap dalam keasyikan media elektronik (gadget), biasanya lupa melakukan interaksi sosial dengan lingkungan dan orang-orang di sekelilingnya. Hal ini menyebabkan anak menjadi kurang empati, tidak berinisiatif untuk membina hubungan dengan teman sebaya, tidak dapat mengatasi konflik yang mungkin terjadi dan dapat mempengaruhi aspek emosinya dalam bersosialisasi dengan orang lain. Menurut Romo (2013) bermain gadget dalam durasi yang panjang dan dilakukan setiap hari secara kontinyu, bisa membuat anak berkembang ke arah pribadi yang antisosial. Menurut Kathleen Stassen Berger, sikap antisosial tersebut tidak mempertimbangankan penilaian dan keberadaan orang lain yang ada di sekitarnya. Sikap antisosial ini biasa dilakukan dalam bentuk menyendiri, sedikit berbicara, berbohong dan sulit beradaptasi dan biasanya menolak dan menarik diri untuk berbagi dan membantu orang lain serta tidak peduli terhadap lingkungan sekitarnya. Perilaku ini dapat mengakibatkan dirinya sendiri menjadi tidak mampu menjalankan tugas dan pekerjaannya dengan baik, baik pekerjaan sekolah maupun pekerjaan rumah, mengakibatkan kerugian bagi masyarakat maupun lingkungannya seperti merusak integrasi sosial, mengganggu keamanan dan ketertiban umum, karena seseorang yang memiliki sikap antisosial ini tidak mematuhi norma-norma dan peraturan yang ada di lingkungan tempat dia berada serta memungkinkan terjadinya konflik antar kelompok.

Dalam hal ini orang tua dan sekolah sangat berperan penting dalam kegiatan yang dilakukan oleh anak-anak mereka. Peran orang tua disini dapat berupa perhatian, dukungan dan pengawasan pada anaknya mengenai penggunaan media elektronik (gadget) tersebut. Adapun beberapa cara yang dapat membantu orang tua untuk menghindari kecanduan gadget pada anak mereka diantaranya adalah mengawasi dan membatasi penggunaan gadget pada anak dengan bersikap tegas dalam waktu penggunaan gadget sehingga anak dapat membagi waktu yang baik dan benar dalam menjalankan aktivitasnya sehari-hari dan tidak mengganggu aktivitasnya. Berdiskusilah dengan anak dengan memulailah dari diskusi yang ringan dan terbuka dengan anak tentang batasan-batasan yang ditetapkan karena keluarga merupakan orang terdekat yang lebih sering melakuakn interksi dengan anak. Dengan melakukan diskusi-diskusi kecil tersebut anak mulai merasakan pentingnya dan perlunya komunikasi dan interaksi dalam keluarga maupun lingkungan di luar keluarga. Melibatkan anak dalam aktivitas fisik di luar rumah, seperti bersepeda dan kegiatan lainnya, tetapkan aturan penggunaan gadget, sediakan buku/games edukasi di rumah karena dengan melakukan kegiatan-kegiatan tersebut dapat membantu anak untuk kembali di dalam periode proses perkembangan sosial secara normal dan sesuai dengan tahapan perkembangan. Demikian juga dengan pihak sekolah, ada batasan-batasan yang perlu diperhatikan, yaitu membuat peraturan untuk tidak memperbolehkan membawa atau menggunakan gadget pada jam sekolah, menyediakan fasilitas sekolah yang memadai untuk kebutuhan belajar bagi siswa dan siswi, dan bila ada tugas sekolah yang harus menggunakan gadget perlu adanya pengawasan dalam penggunaannya. Dengan latar belakang ini perlu dilakukan penelitian guna mengetahui hubungan penggunaan media elektronik (gadget) dengan perkembangan sosial anak usia sekolah.

\section{Metode}

Penelitian ini menggunakan metode korelasional yaitu metode penelitian yang mengkaji hubungan antara variabel dengan tujuan mengungkapkan korelatif antar variabel (Setiadi, 2007). Pada penelitian ini tujannya adalah untuk mengetahui hubungan 
media elektronik (gadget) dengan perkembangan sosial anak usia sekolah.

Pada penelitian ini populasinya adalah semua siswa kelas IV dan V di Madrasah Ibtidaiyah Darusalam Pagesangan Surabaya yang mempunyai gadget. Kriteria sampel pada penelitian ini adalah siswa kelas IV dan V yang mempunyai gadget yang berjumlah 73 siswa.

Pengambilan data dilakukan dengan penyebaran kuisioner kepada siswa yang menjadi sampel. Dalam penelitian ini terdapat dua kategori kuesioner yakni kategori penggunaan media elektronik (Gadget) dan kategori perkembangan sosial anak usia sekolah. Penggunaan media elektronik terdapat 12 pertanyaan mengenai Penggunaan gadget, waktu penggunaan gadget, frekuensi penggunaan gadget dan tujuan penggunaan gadget. Setiap pertanyaan mempunyai skor masing-masing untuk pertanyaan positif: skor 4: Sangat Sering, skor 3: Serinng 2: Kadang-kadang, Skor 1: Tidak pernah. Dan untuk pertanyaan negatif: skor 4: Tidak pernah, skor 3: kadang-kadang, skor 2: sering, skor 1: sangat sering. Nilai maksimal dari skor adalah $12 \times 4=48$ dan niali minimal adalah $1 \times 12=12$. Kesimpulannya: baik, jika nilai 36-48, cukup, jika nilai $24-35$ dan kurang, jika nilai 12-23. Dan untuk kategori perkembangan sosial anak terdapat 32 pertanyaan. Setiap pertanyaan mempunyai skor masing-masing mempunyai skor 4: Sangat sering, skor 3: Sering, skor 2: Kadang-Kadang, skor 1: Tidak Pernah, Kesimpulannya: perkembangan sosial dikatakan tinggi, jika nilainya 97-128 sedang jika nilainya $65-96$ dan rendah jika nilainya 32-64.

\section{Hasil}

Gambaran Umum Lokasi Penelitian

Di MadrasaH Ibtidaiyah Darussalam terdapat beberapa kegiatan untuk siswa seperti kegiatan pesantren kilat yang dilaksanakan pada setiap bulan Ramadhan setiap tahunnya, pelaksanaan upacara bendera setiap hari senin, kegiatan piket sekolah setiap hari, gotong royong di lingkungan sekolah dan penambahan jam pelajaran. Madrasah Ibtidaiyah Darussalam juga mempunyai peraturan untuk siswa dan siswi yaitu tidak diperbolekan menggunakan atau membawa alat elektronik seperti handphone ke sekolah.

\section{Data Umum}

\section{Tabel 1. Karakteristik responden berdasarkan usia}

\begin{tabular}{llll}
\hline No. & Usia & $\begin{array}{l}\text { Jumlah } \\
\text { responden }\end{array}$ & $\begin{array}{l}\text { Persen } \\
(\%)\end{array}$ \\
\hline 1 & $\begin{array}{l}10-11 \\
\text { tahun }\end{array}$ & 59 orang & $80,8 \%$ \\
2 & $\begin{array}{l}11-12 \\
\text { tahun }\end{array}$ & 14 orang & $19,2 \%$ \\
\cline { 2 - 4 } & Total & 73 orang & $100 \%$ \\
\hline
\end{tabular}

Berdasarkan tabel 1 dapat diketahui responden terbanyak berusia 10-11 tahun dengan jumlah responden 59 orang $(80,8 \%)$.

\section{Tabel 2. Karakteristik responden berdasarkan jenis kelamin}

\begin{tabular}{|c|c|c|c|}
\hline${ }_{0} \mathrm{~N}$ & $\begin{array}{l}\text { Jenis } \\
\text { keamin }\end{array}$ & $\begin{array}{l}\text { Jumlah } \\
\text { Responden }\end{array}$ & $\begin{array}{l}\text { Persen } \\
(\%)\end{array}$ \\
\hline 1 & Laki-laki & 37 orang & $\begin{array}{l}50,7 \\
\%\end{array}$ \\
\hline 2 & Perempuan & 36 orang & $49,3 \%$ \\
\hline & Total & 73 orang & $100 \%$ \\
\hline
\end{tabular}

Berdasarkan tabel 2 dapat diketahui responden terbanyak yaitu berjenis kelamin laki-laki dengan jumlah 37 orang $(50,7 \%)$.

\section{Tabel 3. Karakteristik responden berdasarkan pekerjaan orangtua}

\begin{tabular}{|c|c|c|c|}
\hline No & $\begin{array}{l}\text { Pekerjaan } \\
\text { Orangtua }\end{array}$ & $\begin{array}{l}\text { Jumlah } \\
\text { Responden }\end{array}$ & $\begin{array}{l}\text { Persen } \\
(\%)\end{array}$ \\
\hline 1 & PNS & 7 orang & $9,6 \%$ \\
\hline 2 & Wirausaha & 10 orang & $13,7 \%$ \\
\hline 3 & $\begin{array}{l}\text { Pegawai } \\
\text { Swasta }\end{array}$ & 40 orang & $54,8 \%$ \\
\hline 4 & $\begin{array}{l}\text { Tidak } \\
\text { bekerja }\end{array}$ & 2 orang & $2,7 \%$ \\
\hline 5 & Lain-lain & 14 orang & $19,2 \%$ \\
\hline & Total & 73 Orang & $100 \%$ \\
\hline
\end{tabular}


Berdasarkan tabel 3 dapat diketahui responden terbanyak dari pekerjaan orangtua responden adalah pegawai swasta dengan jumlah 40 orang $(54,8 \%)$.

\section{Tabel 4. Karakteristik responden berdasarkan pendidikan terakhir orangtua}

\begin{tabular}{llcc}
\hline No & $\begin{array}{l}\text { Pendidikan } \\
\text { Akhir } \\
\text { Orangtua }\end{array}$ & $\begin{array}{l}\text { Jumlah } \\
\text { Responden }\end{array}$ & $\begin{array}{l}\text { Persen } \\
(\%)\end{array}$ \\
\hline 1 & SD & 7 orang & $9,6 \%$ \\
2 & SMP & 14 orang & $19,2 \%$ \\
3 & SMA & 36 orang & $49,3 \%$ \\
4 & Perguruan & 16 orang & 21,9 \\
& Tinggi & 73 0rang & $100 \%$ \\
\hline
\end{tabular}

Berdasarkan tabel 4 dapat diketahui responden terbanyak dari pendidikan akhir orangtua adalah SMA yaitu 36 orang (49,3 $\%)$.

\section{Tabel 5. Karakteristik Responden Berdasarkan Orangtua responden yang Memiliki Gadget}

\begin{tabular}{llll}
\hline & $\begin{array}{l}\text { Orangtua } \\
\text { Nang } \\
\text { memiliki } \\
\text { gadget }\end{array}$ & $\begin{array}{l}\text { Jumlah } \\
\text { Responden }\end{array}$ & $\begin{array}{l}\text { Persen } \\
(\%)\end{array}$ \\
\hline 1 & Ya & 61 orang & $83,6 \%$ \\
2 & Tidak & 12 orang & $16,4 \%$ \\
\hline & Total & 73 0rang & $100 \%$ \\
\hline
\end{tabular}

Berdasarkan tabel 5 dapat diketahui responden terbanyak dari orangtua responden yang menggunakan gadget adalah 61 orang $(83,6 \%)$.

Data Khusus

Tabel 6. Karakteristik Penggunaan media Elektronik (Gadget)

\begin{tabular}{llll}
\hline No. & $\begin{array}{l}\text { Penggunaa } \\
\text { n Gadget }\end{array}$ & $\begin{array}{l}\text { Jumlah } \\
\text { Responden }\end{array}$ & $\begin{array}{l}\text { Perse } \\
\mathrm{n}\end{array}$ \\
\hline 1 & Tinggi & 9 orang & $\begin{array}{l}12,3 \\
\%\end{array}$ \\
2 & Sedang & 63 orang & $\begin{array}{l}86,3 \\
\%\end{array}$ \\
3 & Rendah & 1 orang & $1,4 \%$ \\
\hline & & Total & $100 \%$ \\
\hline
\end{tabular}

Berdasarkan tabel 6 dapat diketahui penggunaan media elektronik (Gadget) sebagian besar penggunaannya sedang dengan jumlah 63 orang $(86,3 \%)$.

Tabel 7. Karakteristik Perkembangan Sosial Anak Usia Sekolah

\begin{tabular}{lllr}
\hline No. & $\begin{array}{l}\text { Perkembangan } \\
\text { social }\end{array}$ & $\begin{array}{l}\text { Jumlah } \\
\text { Responden }\end{array}$ & Persen \\
\hline 1 & Baik & 64 orang & $87,7 \%$ \\
2 & Cukup & 9 orang & $12,3 \%$ \\
3 & Kurang & 0 orang & $0 \%$ \\
\hline & & Total & $100 \%$ \\
\hline
\end{tabular}

Berdasarkan tabel 7 dapat diketahui sebagian besar 64 orang $(87,7 \%)$ responden anak usia sekolah memiliki perkembangan soaial yang baik.

Tabel 8. Distribusi frekuensi responden penggunaan media elektronik (gadget) dengan perkembangan sosial anak usia sekolah

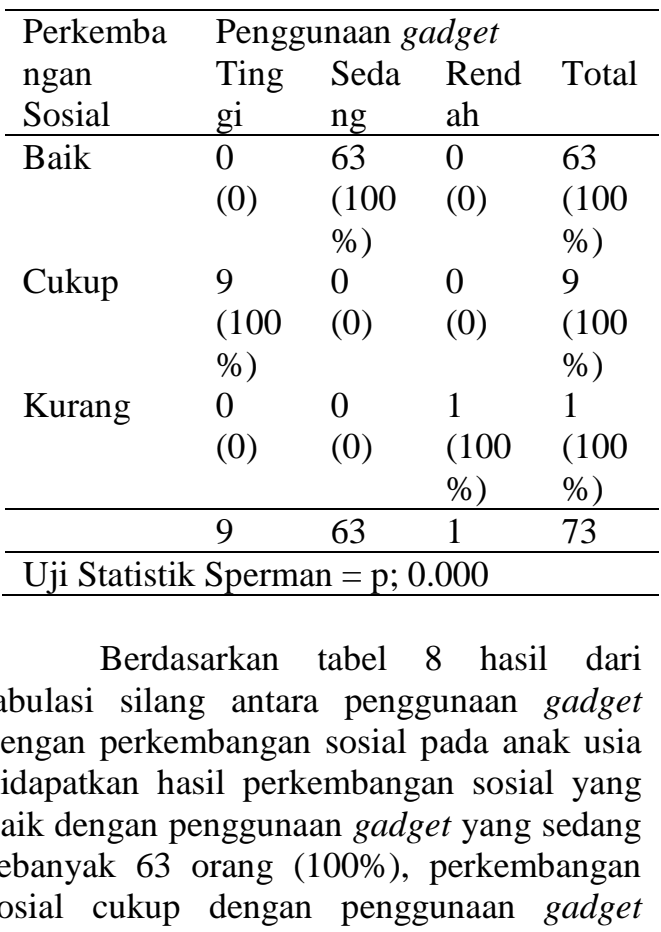


tinggi sebanyak 9 orang $(100 \%)$, dan perkembangan sosial yang kurang dengan penggunaan gadget rendah sebanyak orang $(100 \%)$. Hasil uji statistik dengan Sperman = p; 0,000 dengan nilai kemaknaan $\mathrm{p}<0,005$ yang berarti $\mathrm{H} 0$ ditolak yang artinya ada hubungan antara penggunaan media elektronik (gadget) dengan perkembangan sosial anak usia sekolah di Madrasah Ibtidaiyah Darussalam pagesangan Surabaya.

\section{Pembahasan \\ Penggunaan Media Elektronik (Gadget) pada Anak Usia Sekolah}

Berdasarkan tabel 6 dapat dilihat bahwa penggunaan media elektronik (gadget) di Madrasah Ibtidaiyah Darussalam sebagian besar masih berada pada penggunaan yang sedang sebanyak 63 orang $(86,3 \%)$. Menurut Syifa Amelola (2013) bahwa kemajuan media informatika dan teknologi sudah dirasakan oleh hampir seluruh lapisan masyarakat, bahkan pada umumnya saat ini, anak-anak usia 5 hingga 12 tahun yang menjadi pengguna paling banyak dalam memanfaatkan kemajuan informatika dan teknologi. Setelah melakukan penelitian, penulis mendapatkan hasil dimana penggunaan gadget pada penelitian ini sebagian besar pada tingkat sedang hal ini disebabkan karena hampir semua siswa kelas 4 dan 5 di Madrasah Ibtidaiyah Darussalam sebagian besar memiliki gadget dan dapat mengoperasi fasilitas gadget yang dimiliki. Mereka mengatakan bahwa mereka menggunakan gadget tersebut untuk keperluan mereka sebagai alat komunikasi dengan teman-teman, media hiburan dan juga membantu dalam menyelesaikan tugas sekolah sehingga mereka menganggap bahwa gadget sangat penting bagi kebutuhan mereka. Selain hal tersebut juga mungkin dipengaruhi oleh usia responden yang masih termasuk dalam usia anak sekolah yang sangat berpengaruh pada sifat khas mereka yaitu rasa ingin tahu terhadap hal-hal yang baru. Berdasarkan tabel 1 dapat diketahui responden terbanyak berusia 10-11 tahun dengan jumlah responden 59 orang $(80,8 \%)$. Pada usia ini anak mempunyai minat terhadap kehidupan yang praktis atau instan dan mempunyai rasa ingin tahu terhadap sesuatu sehingga merekapun mempunyai keinginan untuk memiliki gadget dan lebih suka menggunakan media eletronik tersebut. Rasa ingin tahu tersebut membuat anak seusia ini sudah mempunyai gadget dan mampu mengoperasi fasilitas tersebut untuk berkomunikasi, bermain game dan sebagainya. Hal ini didukung oleh Syamsu Yusuf (2014) bahwa masa-masa kelas tinggi sekolah dasar kira-kira usia 10-12 tahun muncul beberapa sifat yang khas pada anak yaitu adanya minat terhadap kehidupan prktis sehari-hari yang konkret, amat realistik, ingin mengetahi dan ingin belajar.

Penggunaan gadget yang sedang pada siswa ini mungkin juga disebabkan oleh harga gadget yang semakin ekonomis sehingga semua kalangan bisa memilikinya. Berdasarkan tabel 3 dapat diketahui responden terbanyak dari pekerjaan orangtua adalah pegawai swasta dengan jumlah 40 orang $(54,8 \%)$. Menurut Wing Winarno (2009) bahwa gadget merupakan alat elektronik kecil yang memiliki fungsi khusus dan membuat hidup manusia menjadi lebih praktis. Hal ini juga didukung oleh Panji Ismail (2013) bahwa dari faktor semakin banyaknya teknologi yang bersaing menyebabkan harga dari gadget semakin terjangkau dimana dulu orang yang mampu membeli gadget hanyalah orang golongan menegah atas, akan tetapi pada kenyataan sekarang orang yang berpenghasilan paspasan pun sudah mampu alat canggih tersebut untuk anak mereka. Jika dilihat dari pekerjaan orangtua dengan penghasilan sebagai pegawai swasta, dapat dikatakan bahwa orangtua dengan pekerjaan tersebut mampu membelikan alat elektronik ini untuk kebutuhan anak mereka. Hal ini dibuktikan pada saat penelitian, siswa mengatakan bahwa mereka mendapatkan gadget dari orangtua mereka untuk digunakan sebagai alat komunikasi jika orangtuanya sedang bekerja, sebagai hadia dari orangtua dan sebagai hiburan (permainan) untuk mereka. Selain itu juga dari data penelitian ditemukan bahwa sebagian besar orangtua responden mempunyai gadget. jika sebagian besar orangtua mampu memiliki gadget maka tidak menutup kemungkinan bahwa mereka pun bisa membelikan media elektronik tersebut untuk anak mereka. penggunaan gadget yang sedang ini jika tidak diperhatikan atau diawasi penggunaannya pada anak usia sekolah maka akan berpengaruh pada perkembangan anak. 


\section{Perkembangan Sosial pada Anak Usia Sekolah}

Berdasarkan tabel 7 dapat dilihat bahwa sebagian besar perkembangan sosial yang baik pada anak usia sekolah yang menggunakan gadget di Madrasah Ibtidaiyah Darussalam sebanyak 64 orang $(87,7 \%)$. Menurut Sunarto dan Hartono (2006) bahwa proses pendidikan yang bertujuan mengembangkan kepribadian anak dalam bersosialisasi lebih banyak ditentukan oleh keluarga dengan norma-norma kehidupan keluarga. Hal ini juga dikuatkan oleh Yee-Jin Shin (2014) bahwa pembentukan perkembangan sosial anak dimulai dari lingkungan terkecil yaitu keluarga, dimana keluarga merupakan lingkungan pertama yang memberikan pengaruh terhadap berbagai aspek perkembangan anak termasuk perkembangan sosialnya. Pengaruh-pengaruh yang diberikan keluarga pada anak dapat berupa pemberian jadwal kegiatan baik di dalam lingkungan rumah maupun diluar lingkungan keluarga sehingga anak dapat menempatkan diri terhadap lingkungan yang lebih luas dan anak menjadi lebih muda terkontrol.

Perkembangan sosial yang baik pada anak salah satunya juga dapat dilatarbelakangi oleh tingkat pendidikan orangtua. Hal ini dapat dilihat pada saat peneliti melakukan penelitian ditemukan sebanyak 36 orang $(49,3 \%)$ orang tua siswa memiliki tingkat pendidikan yang cukup tinggi yaitu SMA. Menurut Mubarak (2011) bahwa semakin tinggi pendidikan seseorang, semakin mudah pula orang tersebut untuk menerima informasi dan akhirnya makin banyak pula pengetahuan yang dimilikinya. Hal ini menunjukan bahwa pendidikan SMA memiliki tingkat pendidikan yang baik sehingga orangtua mampu menerima dan memahami informasi yang didapat tentang penggunaan gadget pada anak usia sekolah. Ini terbukti dari beberapa anak mengatakan bahwa orangtua mereka memberikan batasan-batasan dalam menggunakan gadget seperti pada saat berkumpul bersama keluarga, belajar dan bermain bersama teman anak tidak diperbolekan menggunakan gadget.

Selain hal tersebut juga dapat dipengaruhi oleh pekerjaan orangtua terhadap penyediaan waktu luang yang cukup bagi anak. Berdasarkan tabel 5.3 bahwa sebagian besar orangtua responden bekerja sebagai pegawai swasta yaitu sebanyak 40 orang $(54,8 \%)$. Meskipun bekerja sebagai pegawai swata namun keluarga berusaha untuk menyediakan waktu luang untuk berkumpul dengan anggota keluarga seperti pada saat makan malam bersama, berbincang-bincang dengan anak untuk menanyakan ativitas anak baik di luar rumah maupun di dalam rumah selama orangtua bekerja, dan membantu anak dalam mengerjakan tugas sekolahnya. Sehingga, anak merasa lebih senang dan nyaman berada di lingkungan keluarga bersama anggota keluarga dan dapat bersosialisasi dengan anggota keluarganya. Menurut Soetjiningsih (2002) bahwa interaksi didalam keluarga akan menentukan pola dan tingkah laku anak terhadap orang lain dalam lingkungan sekitar. Anak yang merasa diperhatikan dan disayangi oleh anggota keluarga akan merasa nyaman dan tidak takut bersosialisasi dengan oranng lain.

Berdasarkan tabel 5.1 dapat diketahui responden terbanyak berusia 10-11 tahun dengan jumlah responden 59 orang $(80,8 \%)$ dan usia 11-12 tahun sebanyak 12 orang (19,2\%). Menururt Syamsu Yusuf (2014), setelah anak memasuki sekolah, anak akan melakukan hubungan yang lebih banyak dengan anak lain sebagai proses belajar untuk menyesuaikan di dengan norma-norma kelompok, tradisi dan moral dan pada saat itu juga permainan yang bersifat individual menggantikan permainan kelompok. karena pada usia ini anak mulai memiliki kesanggupan menyesuaikan diri sendiri, mampu bekerjasama dan mau memperhatikan kepentingan orang lain keadaan ini pun selanjutnya ditambahkan lagi oleh Syamsu Yusuf (2013), bahwa perkembangan sosial pada anak-anak sekolah dasar ditandai dengan adanya perluasan hubungan, disamping dengan keluarga atau teman kelas sehingga ruang gerak hubungan sosialnya semakin bertambah luas. Hal ini terbukti dari hasil saat dilakukan penelitian dimana siswa/i MI Darussalam selalu berkumpul dan bermain bersama temantemannya pada jam istirahat dan selalu mengikuti kegiatan-kegiatan yang dibuat oleh pihak sekolah untuk mengembangkan sikap sosial siswa/i tersebut seperti mereka mengikuti kegiatan pesantren kilat yang 
diadakan pada setiap bulan suci Ramadhan pada tiap tahunnya, mereka melaksanakan upacara bendera pada setiap hari senin, menjalankan piket sekolah setiap hari secara bergilir, gotong royong di lingkungan sekolah walaupun itu menyita waktu mereka namun sangat membantu siswa Madrasah Ibtidaiyah Darussalam untuk bersosialisasi dan berinteraksi dengan teman kelompoknya selain itu juga pihak sekolah menerapkan peraturan untuk tidak diperbolehkan menggunakan gadget dan membawa gedget tersebut ke wilayah sekolah. Usaha-usaha dari pihak sekolah ini sangat membnatu siswa sehingga perkembangan sosial siswa/i tersebut masih tergolong baik dan sesuai dengan perkembangan sosial anak sekolah pada umumnya.

\section{Hubungan Penggunaan Media Elektronik (Gadget) dengan Perkembangan Sosial Anak Usia Sekolah}

Berdasarkan hasil penelitian tersebut dapat diketahui bahwa penggunaan media elektronik mempengaruhi perkembangan sosial anak. Hal ini dapat dilihat pada tabel 8 bahwa dari 73 siswa responden yang menggunakan gadget dalam batasan tinggi sebanyak 9 orang (12,3\%), penggunaan gadget dalam batasan sedang sebanyak 63 orang $(86,3)$ dan penggunaan gadget dalam batasan rendah sebanyak 1 orang $(1,4 \%)$. Sedangkan untuk perkembangan sosialnya, dari 73 siswa/i responden yang memiliki perkembangan sosial yang baik sebanyak 64 orang $(87,7 \%)$ dan yang memiliki perkembangan sosial yang cukup sebanyak 9 orang (12,3\%). Menurut (Elizabeth $\mathrm{T}$. Santoso, 2015), penggunaan media elektronik (gadget) dalam batasan yang masih wajar dan akan membuat perkembangan sosial anak menjadi baik dan matang. Hasil uji statistik dengan Spearman $=p: 0,000$ dengan nilai kemaknaan $\mathrm{p}<0,005$ yang berarti H0 ditolak yang artinya ada hubungan antara penggunaan media elektronik gadget dengan perkembangan sosial anak usia sekolah di Madrasah Ibtidaiyah Darussalam Pagesangan Surabaya. Hal ini sesuai dengan teori yang dikemukakan oleh Iswidharmanjaya dan Agency (2014) tentang penggunaan gadget pada anak, yaitu ketika anak sudah asyik dengan gadgetnya, pasti akan menganggap perangkat gadget tersebut adalah bagian dari dirinya sehingga akan mengabaikan lingkungan disekitar, dan akan berdampak buruk bagi perkambangan sosialnya. Tentu saja hal ini akan menghambat proses sosialisasi pada anak terlebih pada anak usia sekolah, karena mereka hanya akan asyik dengan gadgetnya dan lama kelamaan mereka akan bergantung pada gedget tersebut. Tetapi, beda halnya saat seorang anak menggunakan gadget dengan adanya pembatasan atau jadwal yang diberikan oleh orangtua seperti tidak menggunakan gadget pada saat berkumpul bersama anggota keluarga, pada saat makan bersama dan pada saat belajar dan maka perkembangan sosialnya akan berkembang dengan baik walaupun menggunakan media elektronik tersebut. Hal tersebut dapat dilihat dari hasil penelitian bahwa siswa/i dengan penggunaan gadget yang sedang masih memiliki perkembangan sosial yang baik. Tentu saja ini semua dipengaruhi oleh dukungan keluarga dan usaha-usaha para guru dalam mengembangan sikap sosial anak dengan kegiatan-kegiatan sosial. Dukungan keluarga yang dimaksud adalah kasih sayang dari orangtua dan anggota keluarga lainnya walaupun sebenarnya orangtua mempunyai kesibukan, namun selalu memberikan perhatian pada anak sehingga anak merasa nyaman bersama keluarga dan dapat bersosialisasi bersama anggota keluarga. Selain itu juga usaha para guru di sekolah melalui kegiatan-kegiatan sosial yang diadakan seperti kegiatan pesantren kilat yang diadakan pada setiap bulan suci Ramadhan pada tiap tahunnya, upacara bendera pada setiap hari senin, piket sekolah setiap hari secara bergilir, gotong royong di lingkungan sekolah sehingga, anak lebih memahami maksud dari kegiatan-kegiatan sosial yang dilakukan walaupun mereka menggunaan gadget.

Menurut Jovita Maria Ferliana, bahwa dalam menggunakan gadget ada hal-hal yang perlu diperhatikan, diantaranya frekuensi, durasi dan isi/tujuan dari penggunaan gadget. Frekuensi yang baik dalam menggunakan gadget untuk anak usia sekolah adalah 2 hari dalam seminggu yaitu pada hari sabtu dan minggu, sedangkan lamanya waktu penggunaan juga perlu diperhatikan, untuk anak usia sekolah lamanya penggunaan gadget adalah dua jam. Selain itu tujuan/isi dari penggunaan gadget pada anak usia 
sekolah yang seharusnya adalah membantu menambah wawasan dan pengetahuan bagi mereka dan membantu memudakan mereka untuk menyelesaikan tugas-tugas sekolah mereka. Dalam hal ini, jika penggunaan gadget oleh siswa/i sesuai dengan pernyataan diatas, maka akan berdampak baik terhadap perkembangan sosial dari seorang anak tersebut dan anak akan bertumbuh dan berkembang sesuai dengan perkembangan sosial yang semestinya pada anak usia sekolah.

\section{Simpulan}

Penggunaan media elektronik (Gadget) pada anak usia sekolah di Madrasah Ibtidaiyah Darussalam Pagesangan Surabaya sebagian besar pada tingkat sedang.

Perkembangan sosial pada anak usia sekolah di Madrasah Ibtidaiyah Darusalam Pagesangan Surabaya sebagian besar baik.

Ada hubungan penggunaan media elektronik (gadget) dengan perkembangan sosial pada anak usia sekolah di Madrasah Ibtidaiyah Darussalam Pagesangan Surabaya.

\section{Daftar Pustaka}

Ahmadi, Abu H. 2009. Psikologi Sosial. Jakarta: Rineka Cipta

Ameliola, Syfa \& Nugraha, Hanggara Dwiyudha. 2013. Perkembangan media Informasi dan Teknologi Terhadap Anak dalam Era Globalisasi. Prosiding the $5^{\text {th }}$ International Conference on Indonesia Studies: Ethnicity and Globalization.

Cahyaningsih, Dwi Sulistyo. 2011. Pertumbuhan Perkembangan Anak dan Remaja. Jakarta: Trans Info Media

Hurlock, Elizabeth B. (1978). Perkembangan Anak. Jilid 2. Edisi Keenam. 1990. Alih Bahasa: Meitasari Tjandrasa. Jakarta: Erlangga.

Iswidharmanjaya, D., \& Agency, B. (2014). Bila Si Kecil Bermain Gadget. Yogyakarta

Jin Shin, Yee. 2014. Mendidik Anak di Era Digital. Alih Bahasa: Adji Annisa. Jakarta: Noura Books

Manumpil, Beauty. 2015. Hubungan Penggunaan Gadget dengan Tingkat Prestasi Siswa SMA Negri Manado. Ejournal Keperawatan (e-Kep). Vol. 3 No. 2.
Santoso, Elizabetht T. 2015. Raising Children in Digital Era. Jakarta: Gramedia

Santrock, Jhon W. (2008). Psikologi Pendidikan. Edisi 3. 2009. Ahli bahasa: Diana Angelica. Jakarta: Salemba Humanika.

Setiadi. 2007. Konsep \& Penulisan Riset Keperawatan. Yogyakarta: Graha I

Trinika, Yulia. 2015. Pengaruh Penggunaan Gadget terhadap Perkembangan Psikososial Anak Usia Prasekolah di TK Swasta Kristen Immanuel. Nursing Lecture Tanjungapura University

Wong, Donna L. 2003. Pedoman Klinis Keperawaan Pediatrik. Jakarta. Jakarta: EGC

Yusuf, Syamsu. 2014. Perkembangan Perserta Didik. Jakarta: Raja Grafindo Persada 